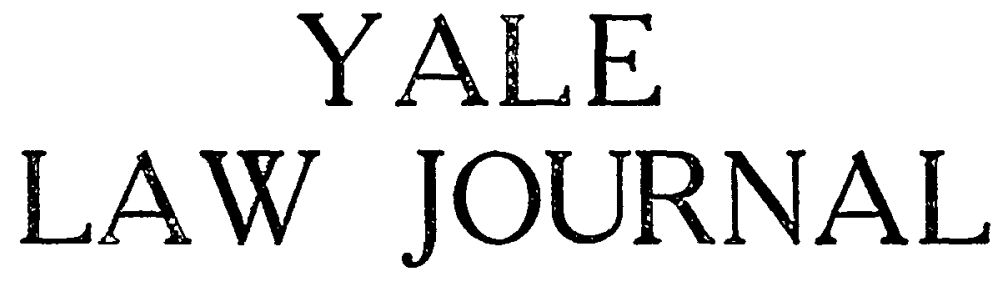

Vol. XXXVII

MARCH, 1928

No. 5

\title{
INCORPOREAL PROPERTY IN PRIMITIVE SOCIETY
}

\section{ROBERT H. LOWIE}

Among the problems that exercised the minds of the earlier evolutionists who dealt with human society, that of property was one of the most important. Its influence in modern industrial civilization was potent; hence the evolutionary schematist naturally assumed that in the earliest phases of culture it had been nil. Lewis H. Morgan's views may be taken as representative. He distinguished three major periods, - Savagery, Barbarism, and Civilization. The beginnings of Barbarism were defined by the invention of pottery, those of Civilization by the use of a phonetic alphabet and literary records. The two former periods were subdivided each into a Lower, Middle, and Upper Status. It was not until the Middle Status of Barbarism-exemplified by the village life of our Southwestern Indians, of the aboriginal Mexicans and the Peruvians-that Morgan assumed property to have played an important part. Among "savages," he held, property was inconsiderable.

"Their ideas concerning its value, its desirability and its inheritance were feeble. Rude weapons, fabrics, utensils, apparel, implements of flint, stone and bone, and personal ornaments represent the chief items of property in savage life. A passion for its possession had scarcely been formed in their minds, because the thing itself scarcely existed." 1

In short, Morgan does not deny that pre-ceramic savages had chattels, but he minimizes the importance of the property held, and of the correlated acquisitive urge. His successors have generally followed his leadership and assumed as a matter of course that on primitive levels property rights were weally developed, there being a far-reaching communistic trend; and, specifically, that land was not appropriated by individuals or even families in the hunting stage.

1 MIORgaN, ANCIENT SOCIETY (1877) pt. IV, c. 1. 
These propositions are no longer tenable. In part they rest on ignorance of the ethnographic data, often on a failure to discriminate between moral and legal prescriptions. To illustrate the latter point, it is unquestionably customary to share the necessaries of life in a manner that sometimes amounts to practical communism; yet, as a rule, in strict aboriginal law the line is clearly drawn between what is one's actual due and what is merely an ethical claim. There are, indeed, extreme instances. In northeastern Siberia a boat lying idle may be put to effective use without the "owner's" consent, nor is the borrower liable for damages in case of injury. Yet among these same populations, other forms of property are jealously guarded from encroachment. As for land, Seligmann has shown that the Vedda of Ceylon not only own tracts individually but practice a form of conveyance; and the prominence of huntingterritories among our Northeastern Algonkians of New England and Eastern Canada has been extensively described by Professor Speck. ${ }^{2}$

This position is fully borne out by data on two genuinely "savage" groups, in Morgan's sense-the Yamana (Yaghan), the most southerly of South American tribes, and the Semang, a Negrito people of the Malay Peninsula.

The Yamana, in particular, exemplify the mingling of ethical and legal principles that has sometimes in the past misled sociological interpretation. Here there does not happen to be individual or family ownership of an economically valuable area, which is held to belong to the entire territorial group. Certain raw materials, such as iron pyrites for fire-making and a species of tree whose bark was suitable for the native types of canoe, were restricted to definite localities; and in these instances, utilization was permitted to territorial groups other than those within whose normal range these natural resources happened to lie. Nevertheless, personal property rights were recognized and, as usual, they rested on individual manufacture and effective use. Baskets must be bought from women, harpoons from men; as elsewhere in North and South America, even the children's claims to ownership are respected. While most of these chattels were burnt with the corpse, a dog was invariably inherited by the eldest son or some other kinsman or acquaintance. Food is treated in the quasi-communistic fashion often reported for primitive tribes. In a particular case a successful sealhunter immediately divided his kill into seven portions, of which he retained two, dividing the remainder among the five tribesmen present. Similarly, it is considered self-evident that the discoverer of a stranded whale should not play the part of a

\footnotetext{
2 Lowie, Primitive Society (1920) c. 9.
} 
miser but should forthwith spread the glad tidings. Yet it is interesting to note that he had a prior claim to the booty and might select favored pieces or direct the distribution. However, no one was privileged simply to appropriate his neighbor's food, and any one who abused the privilege of hospitality soon fell in public estimation. There was also a pronounced tendency to make presents, whether of food, necklaces, slings, spears, or other implements ; and acceptance involved the obligation of making a suitable return gift. The very fact of this institution constitutes proof of individual property rights. ${ }^{3}$

For the Semang the same general principle holds. Clothing and tools are personal property and can be borrowed only with the owner's consent. Husband and wife pool their possessions without relinquishing their separate claims, and neither spouse inherits from the other. The hut belongs to its normal builder, $i$. e., the woman, so that a divorced husband is obliged to leave it. Food is, indeed, shared with fellow-tribesmen, at least so far as they are related. However, two species of trees, the durian fruit-tree and the ipoh, which furnishes arrow-poison, are owned individually. To every adult male belong one or more ipohs and several scattered durian trees. No one would venture to trespass on these prerogatives by cutting into an ipoh or climbing a durian trunk:

The dogma of general primitive communism is, however, at once eliminated by the wide prevalence of individually owned forms of incorporeal property. Their very existence-sometimes on very rude levels, indeed, and alongside of virtual communism in other directions, is a noteworthy phenomenon; and the restrictions on absolute ownership rights imposed by the varying mores of different peoples are no less interesting.

The Eskimo may be profitably studied from this point of view. Lilke the Arctic Siberians', their hunting customs, viewed in isolation, might go far to support the notion that personal ownership is lacking. Yet the magical formulae that secure the Central Eskimo's luck in the chase are not shared communally. One man who was very successful in catching salmon stated that his grandmother had taught him what to sing when fishing. This song for salmon is also effective for seal; but for ground-seal he must sing another one, and still others for muskoxen and for caribou. He had not taught these songs to his children, but intended to do so before he died. Nor were incantations confined to hunting: anciently people could use them

3 Koppers, Die Formen des Eigentums der Yamana auf Feucrland (1926) 3 NeUE ORDNUNG 1-22.

" Schebesta, Bei den URWaldzwergen von Mialaya (1927) 78 et seq., 22J. 
to shorten their journeys, but while reciting a spell of this category they were not allowed to look back. ${ }^{5}$

Fuller data are available for the corresponding phenomena among the Greenland Eskimo. Spells are emphatically private property (en privat og hemmelig eiendom, andre ikle maa bruge). They are potent not because of any spiritual agency but through the virtue of the words themselves, even though these are sometimes unintelligible. Some of the spells correspond to household remedies that eliminate the need for calling upon a shaman to treat a patient. The largest number, however, are designed to secure good luck in the chase. To quote Holm:

"The charms are of great antiquity, and are as a general rule handed down from one generation to the other by sale. They are most effective the first time they are used and little by little they lose their power; hence they must not be used except in times of danger, or when they are transferred to another. When the transference takes place, none but the buyer and seller may be present, and in order that they may have effect, they must be paid immediately, and dearly paid too, if there is to be any power in them; but then they do the possessor much benefit. The payment may consist, e.g., of dart points, lance points, or other costly iron work. As they are much reluctant to use the charms without absolute necessity, it is extremely difficult to get to hear them."

One of Holm's informants recited for him a charm he had effectively used when on the point of death. The explorer says: "I paid for hearing it, otherwise it would have lost its power." "

The inconsistency involved in the Eskimo position has already been alluded to: a communistic trend as to economic necessaries is coupled with strict individualism as to the magical means of securing food. Let us also note the limitations imposed. Effectiveness, for one thing, is contingent on purchase: in other words, the owner is not absolute owner in a metaphysical sense, for he cannot give away his spell as a gift without destroying its efficacy-a rather transparent rationalization. How far this view applies to the Central Eskimo instances is doubtful; possibly there the children have a pre-emptive claim to instruction in their elders' sacred knowledge.

Among the Arctic Northeast Siberians similar conceptions hold sway. The incantations sung by the Koryak are derived ultimately from the Creator and have a variety of virtues,-curative, game-luring, and what not. They are usually in the custody

${ }^{5}$ Boas, The Eskimo of Baffin Land and Hudson Bay (1907) 15 BuLL. AMER. Mus. NAT. Hist. 153, 506.

61 Thalbitzer, The AMmassalik Eskimo (1914) 87 et seq., 305; 2 ibid. (1923) 248-278; THALbiTZER, EsKimoERNES KULTISKe GUDDOMME (1926) 34. 
of elderly women, who do not lightly divulge their sacred knowledge lest its efficacy be destroyed. A statement of Jochelson's concerning the conveyance of ownership is most illuminating:

"When a woman sells an incantation, she must promise that she gives it up entirely, and that the buyer will become the only possessor of its mysterious power:"

In other words, acquisition of full proprietary rights involves more even than the esoteric formula; it requires also the transfer of a rough equivalent of "good-will." :

This naturally leads to a vindication of the incorporeal character of certain forms of property that at first blush do not appear to merit that designation. For example, a superficial view of the ceremonial complexes commonly transferred among the Plains Indians would emphasize the material contents conveyed. To make the matter concrete, the Blackfoot (Montana, Alberta) had a series of so-called military societies, each of which was entered jointly by a group of approximate age-mates who purchased membership outright from an older group. Thus, the Hidatsa Dog organization of any period comprised individuals all of whom had collectively bought such badges as eaglebone whistles, owl-feather headdresses, and dewclaw rattles from the company preceding them as owners of the ceremonial complex labeled "Dog." In so far as all these and other regalia were tangible objects, the term "incorporeal property" might be challenged in this connection. However, closer scrutiny reveals the fact that a transfer implied much more than a mere purchase of the ordinary character. First of all, the buyers obtained the right to perform a specific dance, and some of their officers gained the prerogative of appropriating any food suspended from the meat-racks in the camp. But even the badges themselves were not prized in themselves but in their proper setting: a dewclaw rattle, for example, could have been imitated by the Kit-fox or Lumpwood society, but unless duly bought in the approved fashion from the rightful owners it was nothing but a travesty of the real article. ${ }^{3}$

This point of view appears still more clearly in the case of the sacrosanct complexes known as sacred bundles. The Beaver bundle of the Blackfoot comprises an amazing variety of disparate objects, such as skins of beavers, muskrats, and wildeats; skins of various birds; and so forth. Naturally, it would not be difficult to duplicate these elements, but it is not in them that

\footnotetext{
${ }^{7}$ Jochelson, Material Culture and Social Organization of the Koryal: (1908) 10 Mient. Amer. Mus. Nat. Hist. 59.

${ }^{8}$ Lowie, Societies of the Hidatsa and Mandan Indians (1913) 11 ANTHnop. PAPERS, AMER. MUUS. NAT. HIST. 225 et seq.
} 
the mystic potency of the Beaver bundle inheres; they are nothing but outward symbols of what is essential, to wit, the privilege to sing certain sacred songs and to perform the ritual associated with the objects.

"At the formal transfer, the ritual is demonstrated as far as possible, four days and nights being required to complete it. In the normal order of events the ex-owner continues to instruct the purchaser for an indefinite period."

Unless a man had received this instruction he would not own anything genuinely valuable. In other words, he buys a series of prerogatives including one or more songs, the right to certain specific modes of behavior, knowledge of the origin myth connected with the bundle, and a tangible object or set of objects within a wrapping, to be guarded and opened according to certain rules.

Why unsanctioned mimicry of the material parts of the bundle would be futile, becomes at once obvious from an exposition of aboriginal theory. The Blackfoot believe that every bundle emanates from a direct revelation by a supernatural power.

"The being appearing in the dream offers or consents upon request to give power for some specific purpose. This is done with more or less ceremony; usually the face and hands of the recipient are painted, songs sung, directions given for involking the power and certain obligations, or taboos, laid upon the recipient. The being conferring power is not content with saying that it shall be, but formally transfers it to the recipient with appropriate ceremonies. This is regarded as a compact between the recipient and the being then manifest, and each is expected to fulfill faithfully his own obligations."

Whenever the ritual is performed, it is supposed to be a faithful replica of the initial transfer. One of the significant phenomena in this whole affair is the original visionary's right to transfer the contract to another, who thus acquires all his predecessor's rights. Only by this quasi-apostolic succession can the rapport with the supernatural world be maintained; hence an invasion of copyright would not help insure the blessings-longevity, health, and happiness-linked with authorized ownership. On the other hand, the genuine proprietor cannot lose the benefits connected with a bundle: "the bundle may be lost or destroyed without seriously damaging the owner, since he owns the ritual which is immaterial." Indeed, certain advantages cling to a former owner even after he has divested himself of his formal privileges. He may be called upon to

\footnotetext{
${ }^{9}$ Wissler, Ceremonial Bundles of the Blackfoot Indians (1912) 8 ANTHRop. PAPERS, AMER. MUS. NAT. Hist. 100, 107, 168 et seq., 272 et seq.
} 
officiate in a ceremony because of his recognized familiarity with it, or may administer a deceased owner's bundle until a proper transfer is consummated, and in either case would pocket a fee.

As regards the transmission of sacred bundles, basic differences divide the Plains tribes. With the Omaha and Pawnee, inheritance by the next of kin takes the place of the Blackfoot notion of transfer. While the Blackfoot do not exclude a son from accession to his father's ceremonial privileges, he must acquire them like any stranger, i.e., by the same formal acts of conveyance, and these more frequently obtain between unrelated tribesmen, though symbolically the purchaser is regarded as the "son" of the seller. An interesting fusion of the two contradictory principles encountered in the area occurs among the Hidatsa. They, unlike the Blackfoot, had sons and daughters regularly acquire a bundle from their own father, but they must invariably pay him for it, one of the brothers afterwards becoming its custodian. In other words, children inherit the right of jointly buying proprietary rights from their own father. The latter retains the privilege of joining in the ritual activities, of singing the songs and offering prayers during a performance. Bound up with each bundle are a host of specific prerogatives, such as using a particular method of painting some object in the bundle. These are purchased on the same occasion as the bundle, but must be paid for separately. "A privilege of this sort may be sold four times by the owner, whereupon he loses all his title to it, as among the Crow in corresponding cases." Here, as among the Blackfoot, the spiritud transfer was essential. In fact, the buyer usually did not get the identical objective constituents of his father's bundle but sought to duplicate them by requisitioning the services of a father's clansman; only if the latter failed in his quest did the father supply what was necessary.

"It was the immaterial proprietary rights to a bundle and its ritual that were established by the transfer ceremony, which transformed a potential into an actual prerogative." 10

The data for the Northern Plains tribes invite nice discussions of the basic character of "ownership" in this connection. On the one hand, it would appear a priori that where property rights are directly conferred by divine or supernatural agency, they must be ipso facto indefeasible. That is, of course, true with reference to human instrumentalities. Full knowledge of the rituals is monopolized by the owner, and any one else speaking

${ }^{10}$ Lowie, Sun Dance of the Shoshoni, Ute, and Hidatca (1919) 16 ANTHROP. PAPERS, AMER. MIUS. NAT. HIST. 415 et seq. 
about them from observation or hearsay is not only limited in his information and almost bound to fall into error, but stands revealed as a poacher encroaching on an alien preserve. However, the supernatural origin of the power held implied its revocability by the source of the blessing. Specifically, any infraction of the rules linked with the bundle was fraught with danger. For example, a Beaver bundle imposed many and onerous restrictions on its Blackfoot possessor. If he comes to the bank of a stream he must not turn back but must cross since he is not supposed to show fear of water in any form. Cooking must never be done outside his tipi, yet its sides may not be lifted, irrespective of the temperature. He must never blow the fire; in case of necessity he is allowed to blow through a pipestem. He cannot take back property borrowed from him. He may not eat of the beaver nor of the birds in the sacred pack. "The narrator," writes Wissler, "was once up in the mountains and was greatly famished. Finally he ventured to eat a grouse. This made him deathly ill." In short, the owner of sacred property is in many respects not its master but its slave.

Another limitation of full ownership has already been mentioned: the owner frequently is not empowered to give his sacred privileges away, he can only sell them, even though it be to his own son or daughter. Thus, the designs painted on members in the initiation ceremony of the Crow Indian Tobacco society were not free for all; each method of decoration represented a prerogative acquired in a specific vision, and was transferable in the usual manner of ceremonial rights.

"Greybull ... had once acquired the painting privilege from his own mother, paying her an ermine shirt, a horse, quilts, and money. He sold the right to Plenty-coups for four horses." 11

Perhaps still more significant is the fact that a bundle owner may be forced to part with his property. In some cases the obligation is apparently moral rather than legal. Thus, Strikesat-night, a Crow woman impoverished by her husband's blindness, coveted a Horse Dance bundle supposed to bring good luck. Direct offers of purchase were declined by the owners. To quote my informant,

"One owner wanted a tent and needed hides tanned. Since I was a good tanner, I went to his wife and offered to tan all the requisite hides without demanding pay outright. I got two hides the first time; they were large. I fixed them nicely, returned them, and said I would fix up the whole lodge for them."

11 Lowie, The Tobacco Society of the Crow Indians (1919) 21 ANTHrop. PAPERS, AMER. MUS. NAT. HIST. 149. 
In this way Strikes-at-night prepared all the hides. Then the woman favored asked what pay the tanner wanted. "No, I want to take your medicine." The beneficiary said, "If you had told me before, I should never have let you finish the hides. Now I can hardly refuse you." Accordingly, she and her husband adopted my informant, conveying the ownership to her. "The other people were telling me I was very cunning because of the way I got the medicine." 12

In the instance just cited the impression conveyed to me was that the compulsion, however strong in a moral sense, was not complete. That is to say, my informant's adopter might have been charged with ungraciousness had she refused to accede to the tanner's demands, but could not have been coerced into acquiescence. But among the Blacifoot the situation was different. A man in dire need might make a vow that if he came out of his difficulty safely he would buy a particular type of bundle.

"Such appeals are usually made to the sun. The vow usually names a particular bundle and is registered before witnesses. In such cases, the owner has no option, to sell being imperative." 13

What results, then, from a survey of ceremonial rights in the Plains is that some of them are unequivocally personal. That is to say, they are not shared even by the next of kin nor do they automatically accrue to the holder's heirs. In this respect, a difference obtains between them and otherwise comparable privileges among the Nootka of Vancouver Island. Here each family has its stock of songs,

"no outsider being permitted to make use of them, unless deputed to do so by the owner ..... Any woman may be hired to sing her ... song at a menstrual potlatch, being paid for her services by the giver of the ceremony."

While some privileges are individual in the sense that they might be withheld from the normal heir under unusual circumstances, the most characteristic ones could not be diverted from the eldest-born son in this region of aboriginal primogeniture, so that the lineage of eldest-born descendants virtually constitute a joint-company as regards the relevant rights.18 Notwithstanding, however, the individual nature of ceremonial ownership in the Plains, the religious and ethical notions bound up

12 Lowie, Minor Ceremonics of the Crow Indians (1924) 21 Axinnnop. PAPERS, ANTER. MIUS. NAT Hist. 331.

13 Wissler, op. cit. supra note 9 , at $155,174$.

14 Sapir, Personal Communication, also, A Girl's Pubcrty Crronony among the Nootka Indians (1913) Trans. Royal Soc. CaNado 67-80. 
with it materially limit full property rights, sometimes even in a definitely legal sense.

Equally instructive are the data from the Trobriand Islands off the east coast of New Guinea. ${ }^{15}$ In his eagerness to emphasize the distinctive types of ownership in different parts of the world, Dr. Malinowski goes so far as to regard it as "a grave error to use the word ownership with the very definite connotation given to it in our own society." Because the meaning we attach to it is linked with highly developed economic and legal conditions he infers that "therefore the term 'own' as we use it is meaningless, when applied to a native society." Worse than that, it "smuggles a number of preconceived ideas into our description." This, however, is manifestly to exaggerate a legitimate point. To be forearmed against the perils of loosely apply. ing our terminology, to be keenly sensible of the uniqueness of any particular society and its institutions, is an excellent thing. But we cannot coin a special word for every shade of possessory right as locally defined in the four quarters of the globe. It is far more important to define all such rights conceptually than to devise an infinite series of labels for them, a demand logically implied in Dr. Malinowski's contention, though his common sense prevents him from conforming to it.

His discussion of the sociology of canoe ownership, which immediately follows the propositions cited, furnishes excellent illustrations both of his point and our qualification of it. Dr. Malinowski demonstrates conclusively that the toli-waga or "canoe-owner," to use the nearest English equivalent, is not an absolute owner. While he has the right to choose or eliminate his companions on an expedition, his maternal kinsmen "have, according to all native ideas of right and law, a strong claim on the canoe." Further, even unrelated patricians of the community could not easily be excluded in the absence of special cause; and still others would have a moral "de facto right to sail" because of their skill as mariners. Again, it is the toliwaga that assembles the council and broaches the question as to the date of sailing. However, this right of initiative, on closer scrutiny, turns out to be purely nominal, since "both in construction and sailing, the date of enterprise is determined by outward causes, such as reciprocity to overseas tribes, seasons, customs, etc." This same sort of relative property right is distinctive of the "Kula," an extraordinary system of exchange by which arm-shells and necklaces ceremonially prized are exchanged, each gift being repaid by an equivalent counter-gift. Here, Dr. Malinowski points out that the recipient never retains

\footnotetext{
15 Malinowski, Argonauts of the Western Pacific (1922) 81-104, 116-120.
} 
his acquisition for any length of time,-never for more than a year or two, and even this moderate period "exposes him to the reproach of being niggardly." In other words, public sentiment demands that valuables of this type be kept in circulation. Evidently our authority is warranted in saying that this sort of "ownership," esteemed because of the renown coupled with even fleeting possession, is sui generis.

Notwithstanding this admission, however, there is evidence that ownership quite as complete as any found in any community coexists with those more limited forms that have so deeply impressed their reporter. Let us return to the toli-urage. However he may be restricted in the practical utilization of a boat, the honorific title is indefeasibly his. Even when his closest maternal kinsmen collectively apply it to themselves, "this would be an abuse of the term." Further, "the mere privilege of using exclusively this title is very highly valued by the natives;" and though the right of summoning the council and inaugurating a voyage is admittedly nominal, "the formal privilege is strictly confined to the toli-waga, and highly valued," quite apart evidently from the appreciable economic perquisites of the ofice.

To turn to other phases of culture. In the Trobriands, myths are not owned quite so exclusively as in certain other areas, yet particular ones are associated with lineages who "are supposed to possess the most intimate knowledge of the mythical events, and to be an authority in intexpreting them." Dances are more definitely individual property, the original inventor having the right to perform it in his village. "If another village takes a fancy to this song and dance, it has to purchase the right to perform it." Similarly, magical powel- the knowledge of formulae intrinsically potent to achieve desired ends-is rated as a form of property. A very interesting analogy (though with a difference) to certain Plains Indian conditions may be noted. Sometimes matrilineal blood-relatives, who would be the natural heirs under aboriginal law, desire to secure certain goods in their elder's lifetime. In such cases substantial payments must be made by the nephew or the younger brother, c.g., the magic may be taught bit by bit in return for payment in instalments. "After the final payment, the title of ownership is definitely handed over to the younger man." 18 The difference from the Hidatsa bundle concept lies in the fact that apparently material as well as incorporeal goods may be thus acquired by a Trobriander; and, further, an Hidatsa could not inherit the bundle except by making the customary payment.

Disabilities on sex lines introduce us to another category of incorporeal privileges. In the Banks Islands of Mielanesia women

16 Ibid. 185 et seq., 291, 317, 329. 
never drink or prepare kava, and only in quite recent times have they been allowed to watch its preparation. "I never saw my informant more heartily amused," writes Rivers, "than when I told him that I had seen kava being made by a woman in Samoa." ${ }^{27}$ This evidently must be taken in conjunction with the widespread Melanesian and Australian custom of eliminating women from ceremonial life, for on the Banks Islands the use of kava was formerly restricted to those of high rank in the men's fraternity. The sexual division of labor, involving as it does an allotment of onerous tasks, seems to have little in common with the notion of property rights as commonly understood. But it may also imply greater or lesser kudos, and frequently very practical prerogatives. The Formosan women raise millet and sweet potatoes, and it is they, not their husbands and brothers, who superintend the granaries, dealing out daily supplies to the female representatives of the several households. ${ }^{18}$ On the other hand, in many African and Siberian tribes man's concern with the care of cattle disqualifies women from ownership, and cases are known in which remote kinsmen take precedence of daughters in the inheritance of livestock. In short, sex often includes the right to potential ownership of goods, corporeal or incorporeal.

This is naturally only a special form of group ownership. Wherever succession to dignity is regulated by some such principle as primogeniture, the entire group of incumbents, actual and potential, may be conceived as a corporation, the entire membership sharing the same privileges, even though possession and usufruct be limited to one individual at a time. It is this sense of a group interest that of course tends to nullify testamentary dispositions purporting to override established precedent.

A quaint coupling of prerogative with disability is reported from a people of the Upper Nile region. Though a Lango woman is never allowed to hold any but personal belongings, she may veto her husband's proposal to give away a single head of stock, provided it was obtained as a part of her daughter's bride-price. The purpose of the custom is to safeguard the matrimonial prospects of a woman's son, for here, as elsewhere in Africa, the payment for a daughter is supposed to provide her brother with a wife. To put it differently, a woman who has given birth to a girl and married her off acquires thereby a limited control over the compensation offered. ${ }^{10}$

The Lango furnish us with another instructive sample of incorporeal property in disguise. Hunting-territories are owned

171 RIVers, The History of MELANesian Society (1915) 82.

18 MCGOVERN, AMONG THE HEAD-HUNTERS OF FORMOSA (1922) 124 et seg.

19 Driberg, The Lango, a Nilotic Tribe of Uganda (1923) 172. 
individually, and without the owner's consent encroachment by other hunters would be illegal. However, there are responsibilities accompanying prerogative. The tract must be surrounded by a fire-break to ward off conflagrations spreading to or from the plots of fellow-tribesmen. What, it may be asked, is there incorporeal about land? The point is that no man really owns "his" land. Anyone desiring to build on it or to reserve a plot thereon for tillage cannot be denied, even though formal permission must first be sought. In other words, "the won amu owns the hunting rights over the land rather than the land itself." However, he is not liable for damage to the newcomer's house or crops. ${ }^{20}$ This instance recalls comparable data from New Zealand, where the same territory was differently exploited by different households. One family would have a monopoly of the claim to the shellfish or berries found, another reserved the right to dig fern-roots or to hunt rats.21

Enough has been said to demonstrate the reality of incorporeal ownership on the level of illiterate peoples. How vital a part it plays in their lives is at once apparent when we recall the manifold ramifications of the subject inevitable even in this brief exposition. Starting from a juridical concept, we have had to touch the entire scope of cultural phenomena,-not only the proximate fields of social structure and government but the more remote departments of economics, industry, arts, and religion.

20 Ibid. 112, 171.

21 LowIE, op. cit. supra note 2, at 229. 